\title{
Double or Multiple Submissions: A Policy to Reconsider
}

\author{
Naveen Kumar ${ }^{1}$ \\ ${ }^{1}$ Department of Plastic Surgery, Lady Hardinge Medical College, \\ New Delhi, India
}

Indian J Plast Surg:2020;53:459-459

The term double or multiple submission of a manuscript and consequences of having multiple submissions simultaneously are needed to be fully understood. Today, most of the general and specialty journals that are being bounded by the International Committee of Medical Journal Editors ask for the author's declaration during the article submission that the said article has not been submitted, accepted, or is under consideration for publication in any other journal at the time of the submission. It is in accordance with the Ingelfinger rule. ${ }^{1}$ Double submission is completely different from duplicate publication. Most of the journals encourage sequential submission, that is, till the same article has not been rejected or withdrawn from one journal, it cannot be submitted to any other journal. Double or multiple submissions is considered as an unethical act in most of the journals as it amounts to waste of time and money on the part of reviewers and editors of different journals. An interesting article was published in the British Medical Journal in 2005 by Torgerson et al where suggestions were made for adopting a multiple submission policy by various journals. ${ }^{2}$

A recently published article had shown that the average time period required for an article from submission till publication was 10 to 12 months among six scientific plastic surgery journals. ${ }^{3}$ Although with the adoption of online article submission system by most of the journals, the process of getting an article published has sped up over the last decade or so, but still getting an article published in a reputed journal is still a strenuous task on the part of an author.

Sequential submission usually delays or rather deprive the researchers and the patients from the proclamation of research of clinical significance across the globe. ${ }^{2}$ Sequential submission increases the burden on the journal drastically, with the major burnt being borne by the reviewers besides the financial costs borne by the journal. Long delays in the publication of reporting of some clinical findings may lessen the significance of the clinical research.

\begin{abstract}
Address for correspondence Naveen Kumar, MS, MCh, Department of Plastic Surgery, Lady Hardinge Medical College, Connaught Place, New Delhi, 110001, India

(e-mail: drnaveenvmmc@gmail.com).
\end{abstract}

How much unethical is the multiple submission policy on the part of the authors albeit the reviewers and editors have their reasons for considering such submissions as unethical? Efforts are needed to reduce the turnaround time for publication. Journals can adopt a multiple submission policy whereby a researcher would have to furnish the details of the other journals where the same paper has been submitted simultaneously. The researcher would withdraw the article from rest other journals once it got accepted in a particular journal. The author can submit presubmission queries with the editors carrying the summary of the manuscript simultaneously, and then proceed with the journal that delivers some positive response to the author. Lastly, the author may preprint the data and other research findings so as to credit the author for the findings before the publication of the actual paper.

These are the few recommendations that can be suggested to expedite the process of publication taking into consideration the interests of all the three major stakeholders, that is, authors, journal, and reviewers, but it should not be done at the cost of the quality of review process.

\section{Conflict of Interests}

None declared.

\section{References}

1 Relman AS. The Ingelfinger Rule. N Engl J Med 1981;305(14): 824-826

2 Torgerson DJ, Adamson J, Cockayne S, Dumville J, Petherick E. Submission to multiple journals: a method of reducing time to publication? BMJ 2005;330(7486) :305-307

3 Asaad M, Rajesh A, Banuelos J, Vyas KS, Tran NV. Time from submission to publication in plastic surgery journals: the story of accepted manuscripts. J Plast Reconstr Aesthet Surg 2020;73(2):383-390

\section{published online}

November 30, 2020
DOI https://doi.org/

$10.1055 / \mathrm{s}-0040-1721863$

ISSN 0970-0358. (c)2020. Association of Plastic Surgeons of India.

This is an open access article published by Thieme under the terms of the Creative Commons Attribution-NonDerivative-NonCommercial-License, permitting copying and reproduction so long as the original work is given appropriate credit. Contents may not be used for commercial purposes, or adapted, remixed, transformed or built upon. (https://creativecommons.org/licenses/by-nc-nd/4.0/).

Thieme Medical and Scientific Publishers Pvt. Ltd. A-12, 2nd Floor, Sector 2, Noida-201301 UP, India 